\title{
Pressurized Steam Conversion of Biomass Residues for Liquid Hydrocarbons Generation
}

\author{
Francesco Miccio ${ }^{1, *(\mathbb{D})}$, Elettra Papa ${ }^{1}\left(\mathbb{D}\right.$, Annalisa Natali Murri ${ }^{1}\left(\mathbb{C}\right.$, Elena Landi $^{1}\left(\mathbb{D}\right.$ and Matteo Minelli $^{2}(\mathbb{D})$ \\ 1 Institute for Science and Technology of Ceramics CNR, via Granarolo 64, 48018 Faenza, Italy; \\ elettra.papa@istec.cnr.it (E.P.); annalisa.natalimurri@istec.cnr.it (A.N.M.); elena.landi@istec.cnr.it (E.L.) \\ 2 Department of Civil, Chemical, Environmental and Materials Engineering (DICAM), Alma Mater Studiorum, \\ University of Bologna, via Terracini 28, 40131 Bologna, Italy; matteo.minelli@unibo.it \\ * Correspondence: francesco.miccio@cnr.it
}

check for updates

Citation: Miccio, F.; Papa, E.; Natali Murri, A.; Landi, E.; Minelli, M. Pressurized Steam Conversion of Biomass Residues for Liquid Hydrocarbons Generation. Energies 2021, 14, 1034. https://doi.org/ $10.3390 /$ en14041034

Academic Editors: Alvaro Caballero and Alberto-Jesus Perea-Moreno

Received: 2 January 2021

Accepted: 11 February 2021

Published: 16 February 2021

Publisher's Note: MDPI stays neutral with regard to jurisdictional claims in published maps and institutional affiliations.

Copyright: (c) 2021 by the authors. Licensee MDPI, Basel, Switzerland. This article is an open access article distributed under the terms and conditions of the Creative Commons Attribution (CC BY) license (https:// creativecommons.org/licenses/by/ $4.0 /)$.

\begin{abstract}
Biomass residues are often considered as a resource if conveniently converted in fuel and alternative feedstock for chemical processes, and their conversion into valuable products may occur by different pathways. This work is focused on the thermochemical conversion at moderate temperature and in steam atmosphere, a mild process in comparison to hydrothermal liquefaction, followed by extraction of soluble products in a solvent. Such process has been already applied to various residues and here extended to the case of marc, the residual pomace from wine making, largely produced worldwide. A pressurized batch reactor was used for the quantitative determination of produced solid and liquid fractions, and their qualitative characterization was performed by instrumental analyses. The pressurized steam conversion of marc was effective, providing a yield in liquid fraction, upon extraction in solvent, up to $30 \%$ of the raw dried biomass. The use of polar and nonpolar solvent for the extraction of the liquid fraction was inspected. Applied operating conditions, namely residence time in the batch reactor and extraction modality, showed a significant influence on the process performance. In particular, long residence and extraction times and use of nonpolar solvent substantially improved the yield in liquid fraction.
\end{abstract}

Keywords: pyrolysis; liquefaction; bio-oils; biomass; grape residue; steam

\section{Introduction}

Solid biomass residues, either from land maintenance or agriculture activity, are a renewable, abundant and widespread resource for both energy generation and chemicals production [1]. Their utilization as feedstock for civil and industrial processes fully complies with the strategy of sustainable and circular economy [2]. Biomass conversion into suitable products can occur by several thermochemical or biochemical pathways [3] that in some cases are also combined for achieving higher conversion into valuable chemicals, for instance bio-butanol [4]. A challenging option for lignocellulosic residues is offered by the thermochemical pyrolytic treatment or pyrolysis [5], in particular for seasonal byproducts that are abundantly produced in a short time. In fact, the pyrolysis may convert the biomass into intermediate products in thermochemical plants of compact size, e.g., $500 \mathrm{KW}_{\mathrm{t}}$ WoodRoll $^{\circledR}$ technology [6], with the benefit of damping the biomass production peak. The pyrolytic conversion mainly results in the production of biochar, which finds application for combustion/gasification, energy storage, gas adsorption, water purification or soil amendment [7]. In addition, a bio-oil can be produced, rich in oxygenated hydrocarbons deriving from thermal degradation of biomass constituents (lignin, cellulose, hemi-cellulose, extractives) [8].

The solid products of pyrolysis can be easily handled, stored and shipped, improving thus the economics of the whole agro-industrial chain due to the production of secondary raw materials (biochar and bio-oil) with increased value, for instance $2.75 \$ / \mathrm{kg}$ is reported for activated carbon produced by physical method [9]. Conversely, bio-oils are difficult 
to handle, especially when characterized by high acidity, viscosity, toxicity and storage instability, requiring an upgrade into more stable and standard oil [10].

Furthermore, the biologic degradation of the biomass is hindered upon thermochemical treatment, avoiding $\mathrm{CO}_{2}$, methane and odors emissions in the atmosphere, as well as possible bacterial infection of the accumulated stocks and related safety concerns (e.g., spontaneous firing) [11].

The torrefaction of different biogenic materials is a mild pyrolysis process [12] already reported by several authors, who highlighted the benefits of producing a stable compound, the torrefied biomass, with enhanced properties in terms of high carbon and low oxygen content, larger heating values and improved combustion behavior [13]. Furthermore, the torrefied biomass may be easily grinded and pelletized, alone or in combination with other biomass feedstock, yielding a standard commodity fuel for industrial or civil use [14].

Different from torrefaction, the biomass liquefaction under pressurized conditions and in presence of water/steam gives rise to valuable solid and liquid fractions, the former being similar to a biochar, the latter containing several species such as hydrocarbons, alcohols, phenols, fatty acids and other organic moieties [15]. Depending on the pressure values achieved during the process, two different operation modes can be considered:

(i) hydrothermal treatment, operated at temperature of 500-650 K temperature and operating pressures from 4 to $22 \mathrm{MPa}$, and it is oriented to an enhanced conversion of the biomass into liquids (liquefaction) [16]. It requires fine grinding of the original biomass and high steam pressure, even super-critical [17]. In general, it can be hardly carried out under steady-state conditions, and it is currently demonstrated at limited scale only [18].

(ii) pressurized steam conversion (PSC) at moderate temperature and pressure (370-700 K, $0-5 \mathrm{MPa})$, conditions that are more likely achievable in a continuous process. In this respect, PSC was investigated at lab-scale [19] for the conversion of agricultural residues, i.e., olive husks and tomato peels, followed by the subsequent extraction of soluble components contained in the solid fraction by means of an organic solvent (acetone). The research showed that the organic liquid fraction was significantly larger in when a pressurized steam conversion process is compared with respect to the simple torrefaction [20], thus resulting as a more attractive alternative for an industrial exploitation.

The present article reports on the use of pressurized steam conversion process applied to a different agro-industrial residue, i.e., marc, the grape residue from seasonal wine production that is largely available worldwide, with yearly production of about 2.0 Mton in South-Europe [21]. The aim of this work is to extend the emerging method introduced above (PSC) to a different feedstock, and the analysis of the obtained results. Furthermore, the post-extraction of organic fractions is here deeply investigated, also by comparing the use of polar (acetone) and nonpolar (hexane) solvents. The results in terms of thermogravimetric (TG) characterization of the fuel, yield in solid and liquid fractions upon PSC, Fourier-transform infrared spectroscopy (FTIR) and environmental scanning electronic microscopy (ESEM) analyses of obtained samples are presented and discussed in the article.

\section{Materials and Methods}

\subsection{Biomass}

The biomass used for the experimental investigation was marc, the main residue from wine industry containing pressed peels and almost intact grape seeds. The residue was dried in oven at $105^{\circ} \mathrm{C}$ for $1 \mathrm{~h}$ before grinding in a cutting mill (mod. Pulverisette 15 Fritsch, Idar-Oberstein, Germany) equipped with a $5 \mathrm{~mm}$ mesh. Afterwards, it was manually sieved, obtaining almost regular granules in the size range 1.0-3.5 mm (Figure 1).

The residual moisture and ash content were evaluated by thermogravimetric analysis (see below). The high and low heating values (HHV and LHV) were computed on the basis of the chemical composition using the empirical correlation reported below (Equations (1) and (2)) [22]:

$$
\begin{gathered}
\mathrm{HHV}=0.3491 \% \mathrm{C}+1.1783 \% \mathrm{H}+0.1005 \% \mathrm{~S}-0.1034 \% \mathrm{O}-0.0151 \% \mathrm{~N}-0.0211 \% \mathrm{ASH} \\
\mathrm{LHV}=\mathrm{HHV}(\mathrm{MJ} / \mathrm{kg})-2.442(8.936 \% \mathrm{H} / 100)
\end{gathered}
$$




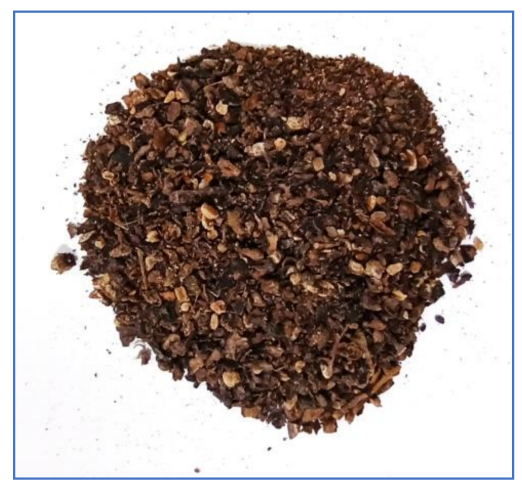

Figure 1. Photograph of dried marc.

\subsection{Reactor}

PSC tests were carried out at the lab-scale, in a pressurized reactor in AISI 316 stainless steel with cylindrical geometry (21 mm inner diameter, $200 \mathrm{~mm}$ height, $48 \mathrm{~mL}$ internal volume), and the layout is illustrated in Figure 2. An electronic pressure transducer and a K-type thermocouple are connected to the reactor, allowing the measurement and the acquisition of internal temperature $(\mathrm{T})$ and pressure $(\mathrm{P})$. A switch valve allows gas inlet and exit. In a single test, biomass sample $\left(\mathrm{M}_{\mathrm{f}}=5.0 \mathrm{~g}\right)$ and deionized water $\left(\mathrm{M}_{\mathrm{W}}\right)$ are loaded to a glass test tube at water-to-fuel mass ratio equal to 1.0. A ceramic wool wad is used to close the open side of the test tube before introducing it into the test reactor, which is finally sealed. The reactor is purged by flowing inert gas $\left(\mathrm{N}_{2}\right)$ into it, in order to keep the system stable. Finally, the stainless steel reactor is quickly introduced into an electric tubular furnace (CARBOLITE 1200, Carbolite LTD, Hope-Hope Valley, England UK) already heated-up at the preset oven temperature $T_{\mathrm{f}}$. That represents time 0 of the PSC experiment, and for its whole duration temperature $\mathrm{T}$ and pressure $\mathrm{P}$ inside the reactor are continuously monitored and recorded.

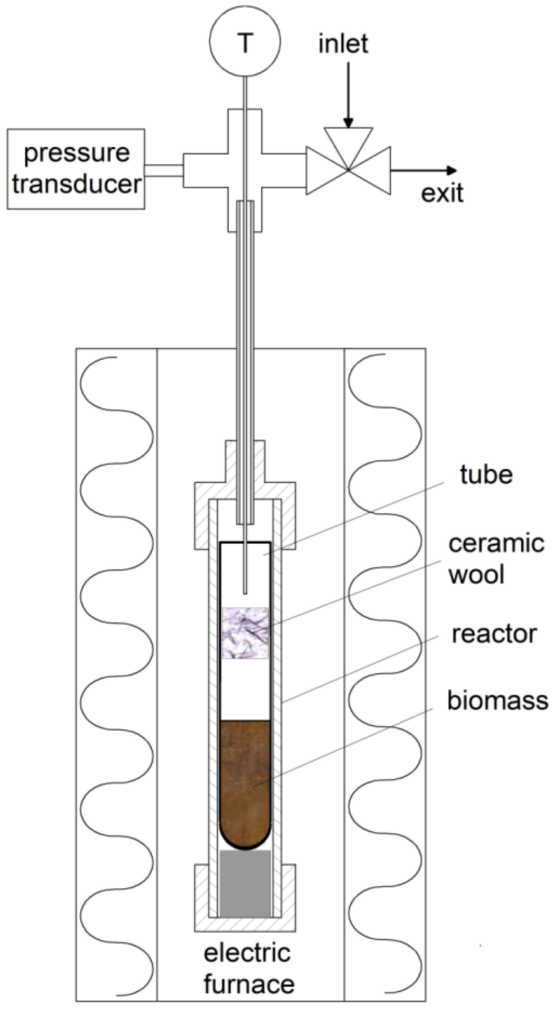

Figure 2. Schematic layout of pressurized reactor for PSC tests. 
The reactor is sealed during the whole test, allowing thus the pressure to be increased, as consequence of water evaporation, release of volatiles from the biomass and inert gas expansion. The test duration was fixed a priori at various values of residence time $\left(t_{r}\right)$, assumed as an operating parameter, ranging from 30 to $120 \mathrm{~min}$, once the reactor temperature reached a stable value $\left( \pm 5^{\circ} \mathrm{C}\right)$. Afterwards, the reactor is rapidly removed from the tubular furnace and cooled in cold water at room temperature. Upon cooling, the valve is opened to allow the discharge of gas and vapors that are expanded into a graduated glass syringe for determination of the volume $\left(V_{G}\right)$ at standard conditions $\left(20^{\circ} \mathrm{C}\right)$. It is noteworthy that this volume does not depend on initial $\mathrm{N}_{2}$ content in the reactor and condensed vapors remain inside the cold reactor. Finally, the reactor is opened and the glass tube extracted.

The sample of the converted biomass recovered from the glass tube is treated with a solvent (acetone or hexane) directly added to the glass tube, for the extraction of the soluble species. After a given extraction time ( 1 or 7 days), the content of the glass tube is filtered on a paper filter (Whatman 43), allowing the separation into a solid fraction and a liquid solution containing the extracted species in the solvent. The solid fraction was stored in desiccator for several days until achievement of stable weight $\left(\mathrm{W}_{\mathrm{S}}\right)$, and after the removal of most of the water content. The moles of the gas phase were calculated from the measured $\mathrm{V}_{\mathrm{G}}$ through the state equation of gases.

The average molecular weight of the gas mixture has been assumed equal to $38 \mathrm{~g} / \mathrm{mol}$ (see below 3.2), so the weight of the gas fraction $W_{\mathrm{g}}$ can be readily calculated. Finally, the mass fractions and yields of the solid $\left(X_{s}\right)$ and gas $\left(X_{g}\right)$ phases are computed by normalization with respect to the initial weight of biomass sample, the liquid fraction $\left(X_{1}\right)$ being computed by complement to one (Equations (3)-(5)).

$$
\begin{gathered}
\mathrm{X}_{\mathrm{s}}=\mathrm{W}_{\mathrm{s}} / \mathrm{M}_{\mathrm{f}} \\
\mathrm{X}_{\mathrm{g}}=\mathrm{W}_{\mathrm{g}} / \mathrm{M}_{\mathrm{f}} \\
\mathrm{X}_{\mathrm{l}}=1-\mathrm{X}_{\mathrm{s}}-\mathrm{X}_{\mathrm{g}}
\end{gathered}
$$

In a limited number of tests, a different procedure was adopted: the exit valve of the reactor is quickly switched after the preset residence time, allowing vapor and gas to leave the hot reactor. In turn, the gas stream is flushed in a bottle immersed in ice, so a liquid fraction is recovered by condensation at $0{ }^{\circ} \mathrm{C}$, allowing thus the condensation of a larger number of volatiles. To ensure the reproducibility of the measurements and the reliability of the results obtained, most of the tests were repeated twice, and the average relative standard deviation was found less than $10 \%$.

\subsection{Analytical Instrumentation}

The ultimate analysis $(\% \mathrm{C}, \% \mathrm{H}, \% \mathrm{~N}, \% \mathrm{~S}, \% \mathrm{O})$ of the dried marc was determined by a CHN628 analyzer (LECO Corp., Saint Joseph, MI, USA). Thermogravimetric and differential scanning calorimetry analyses TG-DSC were performed on dried marc samples under inert $\left(\mathrm{N}_{2}\right)$ and oxidizing conditions $\left(\mathrm{O}_{2} 5 \%\right.$ in $\left.\mathrm{N}_{2}\right)$ up to $1000{ }^{\circ} \mathrm{C}$ with a heating rate of $10^{\circ} \mathrm{C} / \mathrm{min}$ (STA 449C Jupiter, Netzsch, Gaeratebau, Germany). Solid samples were off-line characterized by electronic microscopy (ESEM FEI-QUANTA-200, Thermo Fisher Scientific, Waltham, MA, USA), while FTIR instrumentation Nicolet IS5 (Thermo Fisher Scientific, Waltham, MA, USA) was used in order to obtain qualitative analyses of liquid samples. A mod. GC T-GCX-F1011E-ST0 gas chromatograph (Inficon AG, Bad Ragaz, Swiss) equipped with Molsieve and Rt-Q-Bond columns was used for gas analysis.

\section{Results}

\subsection{Elemental Analysis and Heating Values}

The elemental composition of the dried mark is reported in Table 1, together with the heating values dried marc calculated by Equations (1) and (2). Interestingly, the heating values of the biomass sample are rather high in comparison to other lignocellulosic 
biomass, e.g., coniferous wood $(\mathrm{HHV}=20.4)$ [23], due to the residual presence in grape seeds of vegetable oils. In fact, grape seeds contain $8 \div 20 \mathrm{wt} . \%$ of oil (dry basis), which is mainly composed of unsaturated fatty acids (linoleic and oleic) [24]. The main constituents are those typical of ligno-cellulosic materials: lignin $(\sim 30 \%)$, cellulose $(\sim 14 \%)$, hemicellulose $(\sim 13 \%)$, and poly-phenols ( 15\%) by weight [21].

Table 1. Ultimate analysis and heating value of marc (dry basis).

\begin{tabular}{cc}
\hline Proximate Analysis & \\
\hline Carbon, wt. \% & 57.4 \\
Hydrogen, wt. \% & 6.6 \\
Nitrogen, wt. \% & 2.8 \\
Sulfur, wt. \% & $<0.1$ \\
Oxygen (by difference), wt. \% & 33.2 \\
High heating value HHV, MJ/kg & 23.4 \\
Low heating value LHV, MJ/kg & 22.0 \\
\hline
\end{tabular}

\subsection{Thermogravimetric Analysis}

The results of TG and DSC analyses of dried marc samples under inert and oxidizing conditions are shown in Figure 3, from room temperature to $1000{ }^{\circ} \mathrm{C}$. The weight loss (solid lines) shows an initial drop at $110^{\circ} \mathrm{C}$ due to residual moisture, which can be estimated as high as $8.5 \mathrm{wt}$. \%. Under inert conditions $\left(\mathrm{N}_{2} 100 \%\right)$, the sample exhibits a weight loss of around $65 \%$ below $500{ }^{\circ} \mathrm{C}$, as consequence of complete drying and devolatilization, achieving a final weight equal to $26 \%$ of the initial one (Figure 3a). This residual sample is basically composed by char and ash. Under oxidizing conditions $\left(\mathrm{O}_{2} 5\right.$ vol. \% in $\left.\mathrm{N}_{2}\right)$, very similar behavior can be noticed up temperature of $400^{\circ} \mathrm{C}$, while the residual (solid) carbon conversion takes place up to $800{ }^{\circ} \mathrm{C}$. No further thermal degradation can be detected up to $1000{ }^{\circ} \mathrm{C}$, yielding a final ash content of $3.6 \mathrm{wt} . \%$ (Figure $3 \mathrm{~b}$ ).

(a)

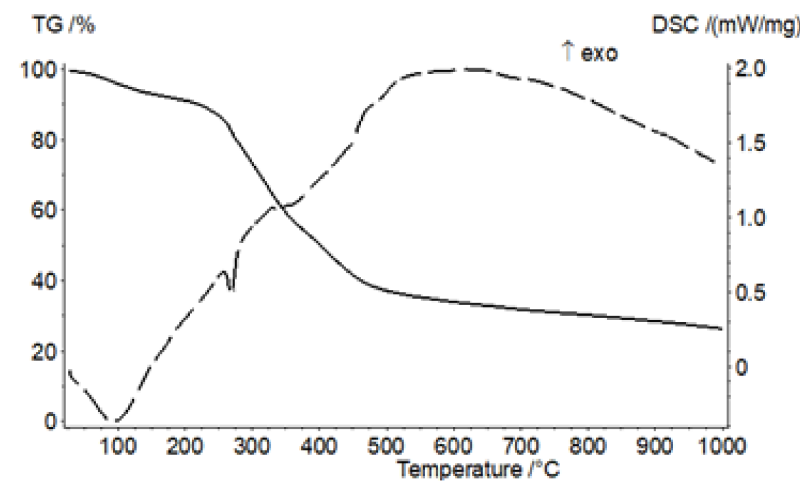

(b)

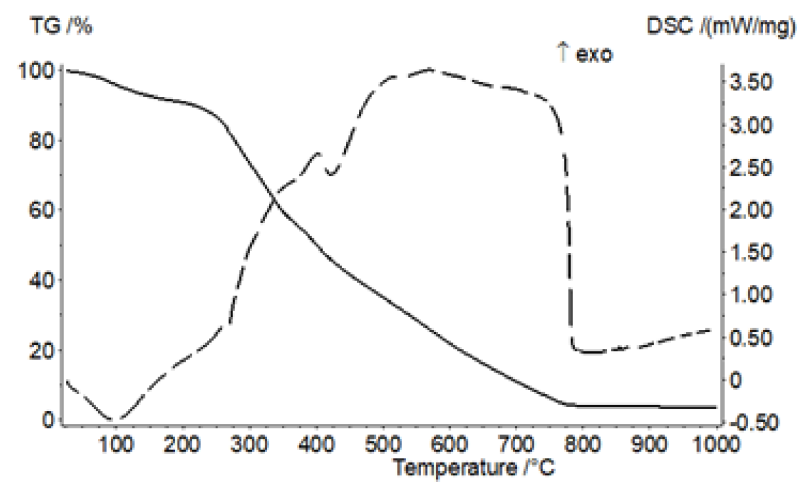

Figure 3. Results of thermogravimetric analyses of dried mark samples ( $38 \pm 3 \mathrm{mg})$. (a) inert atmosphere; (b) oxidizing atmosphere $\left(\mathrm{O}_{2} 5\right.$ vol. \% in $\left.\mathrm{N}_{2}\right)$. Solid line: TG curve; dashed line: DSC curve. 
The DSC signal (dashed lines in Figure 3) shows that the heat treatment is mostly endothermic from room temperature up to $500{ }^{\circ} \mathrm{C}$ in both inert and oxidizing tests. As expected, the footprint of exothermic processes can be detected in the temperature range $500-800{ }^{\circ} \mathrm{C}$ in oxidizing atmosphere, due to combustion of the carbon species (Figure $3 \mathrm{~b}$ ), which provides the release of a significant amount of heat, much larger than in the case of inert environment (Figure 3a). Relevantly, the similar behavior under either inert or oxidizing atmospheres for temperature up to $400{ }^{\circ} \mathrm{C}$ indicated that fuel particles are prevented from the contact with oxidizing species during release of water and volatiles.

\subsection{Pressurized Pyrolysis Reactor}

The typical evolution of temperature and pressure inside the PSC reactor during a transient test is displayed in Figure 4, for the experiment carried out with an oven temperature set at $400{ }^{\circ} \mathrm{C}\left(\mathrm{T}_{\mathrm{f}}\right.$ in the plot). The time evolution of the system reveals that the whole process is quite slow, because of the limited rate of heat transfer between the surrounding furnace operating at relatively low temperature and the reactor tube. The temperature reached a steady level after around $30 \mathrm{~min}$ from the introduction of the reactor into the furnace (set as time 0 ). The increase of pressure was slower, achieving a stable level only in the last 20 min of the test.

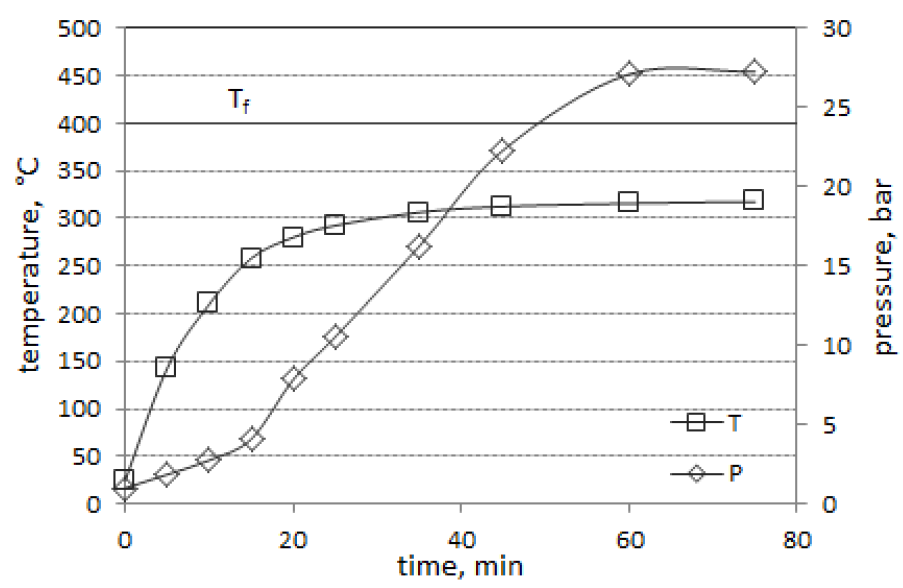

Figure 4. Temperature and pressure profiles during a test of pressurized steam conversion of marc $\left(\mathrm{M}_{\mathrm{f}}=5.0 \mathrm{~g}, \mathrm{M}_{\mathrm{w}}=5.0 \mathrm{~g}\right)$.

Figure 5 shows the mass fractions of solid and liquid products obtained in PSC tests carried at different residence time and subsequent extraction in acetone, along with regression line and $\mathrm{R}$ values. The furnace temperature was set at $400{ }^{\circ} \mathrm{C}$ in all tests and the corresponding final reactor temperature was appreciably lower $\left(\mathrm{T}_{\mathrm{r}}=312 \pm 8^{\circ} \mathrm{C}\right)$ due to heat transfer limitations. Larger conversion times $t_{r}$ allow a small increase of the liquid fraction generated (see also data in associated table), accompanied by a marked decline in solid fraction. The increase of the liquids fraction does not balance the decrease in the solid one, due to the concurrent increase of gas phase, not explicitly reported in Figure 5. It is worth noting that the three fractions are normalized with respect to the initial biomass weight, excluding the added water. The liquid fraction accounts for about $20 \%$ of the initial biomass sample, thus resulting lower than the values reported by Brachi et al. [19] for other residual biomasses, olive husk and tomato peels processed in rather similar conditions. Excluding the $\mathrm{N}_{2}$ initially loaded, the obtained gas fraction was mostly formed by $\mathrm{CO}_{2}\left(30 \div 50\right.$ vol. \%) and $\mathrm{CH}_{4}(20 \div 40$ vol. \%) as revealed by gas-chromatographic analyses, in accordance to Stelte [25].

Figure 6 shows the comparison between the recovered solid and liquid fractions obtained after the same pressurized steam conversion process (at the same operating conditions $T_{f}$ and $t_{r}$ ), but different post treatments of the collected samples: (i) extraction in acetone for 1 and 7 days (cases 1 and 2); (ii) extraction in hexane for 1 day (case 3); (iii) vapor 
condensation in ice trap (case 4). The comparison between different solvents extraction (bars 1 and 3) reveals a more effective extraction of the liquid fraction when hexane is used as solvent. Interestingly, the solid sample after 1 day extraction in acetone and subsequent treatment in desiccator still appeared wet, probably because of a larger solvent sorption in the polar species with respect to the nonpolar one, due to the hydroscopic behavior of biochar [26]. The effect of the extraction time is illustrated in Figure 6 comparing bars 1 and 2: as one can see, the longer the extraction time, the higher the liquid fraction. Finally, the quick discharge of the reactor followed by condensation of volatiles vapors in ice trap at $0{ }^{\circ} \mathrm{C}$ seems the worst option, as it leads to the highest solid fraction and lowest liquid fraction.

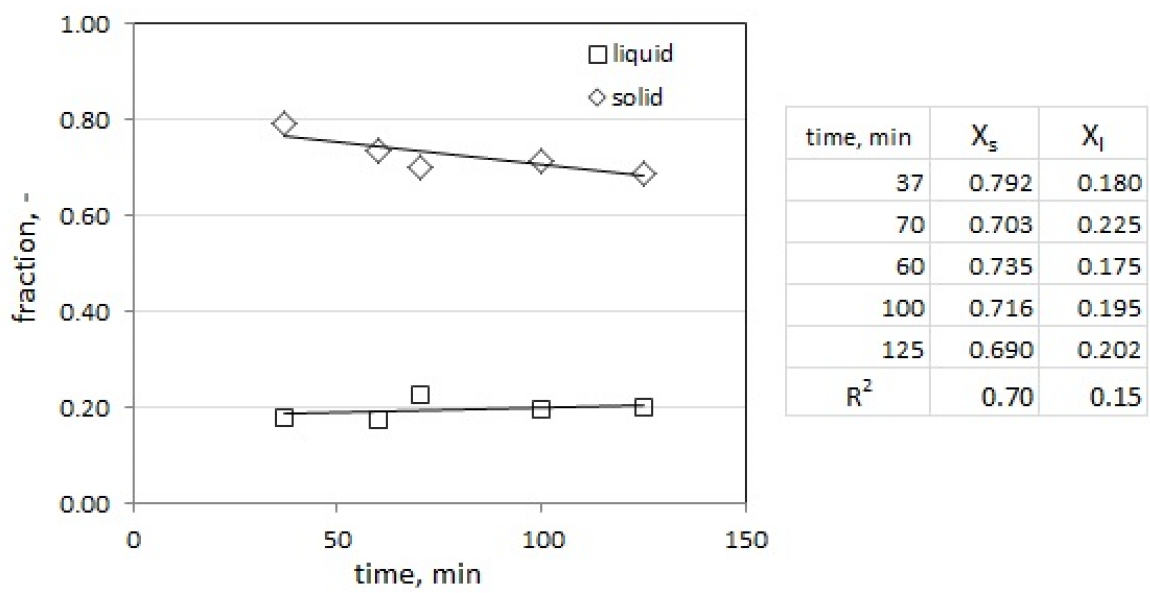

Figure 5. Solid and liquid fractions obtained after PSC tests and acetone extraction as function of residence time in the reactor $\left(\mathrm{T}_{\mathrm{f}}=400 \pm 5^{\circ} \mathrm{C} ; \mathrm{T}_{\mathrm{r}}=312 \pm 8^{\circ} \mathrm{C}\right)$.

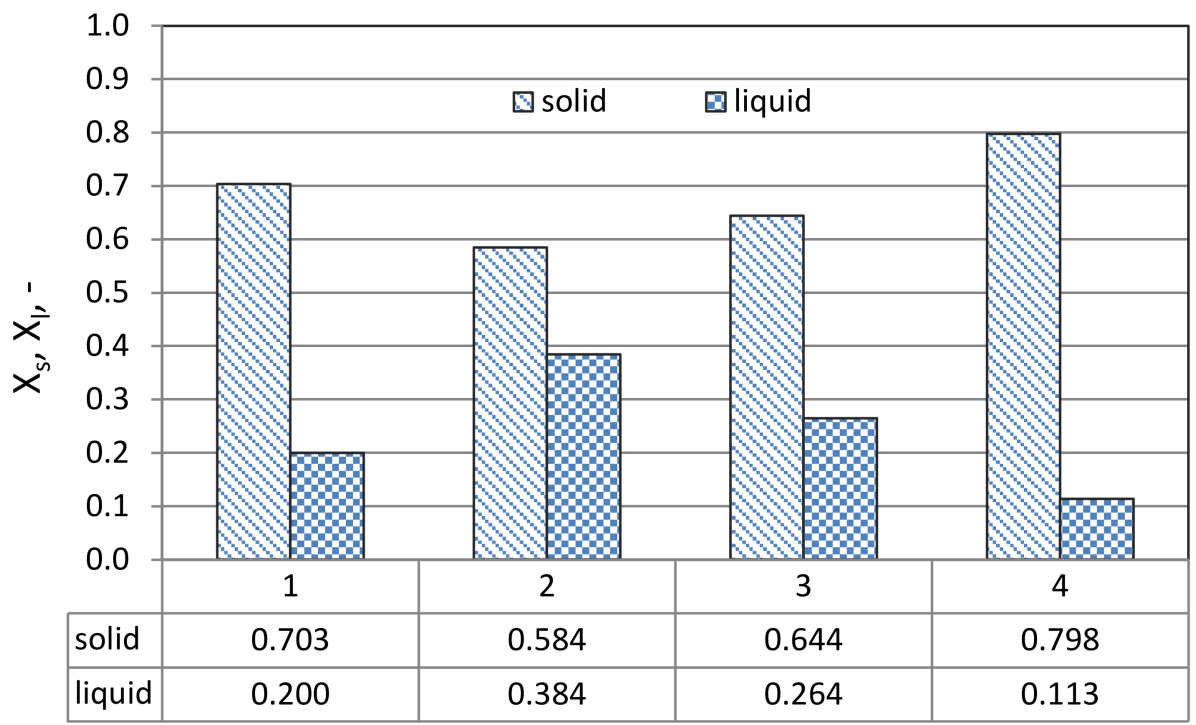

Figure 6. Comparison of liquid fractions obtained after PSC tests with acetone extraction for 1 day (1) and 7 days (2), hexane extraction for 1 day (3) and vapor condensation in ice trap (4). $\mathrm{T}_{\mathrm{f}}=400 \pm 5{ }^{\circ} \mathrm{C}$; $\mathrm{t}_{\mathrm{r}}=60 \mathrm{~min}$.

\subsection{SEM and FTIR Analyses}

The ESEM micro-structural investigations reported in Figure 7 reveals the amorphous microstructure of the as-given biomass (panel a), with locally embedded prismatic crystals or globular phases. The pressurized steam conversion and further extraction with solvent produced the diffused crystallization of mineral phases on the surface of the grains (panels 
b and c), where acicular, flake- and flower-like crystals could be randomly spotted out, along with the globular phases already identified in the untreated sample. Moreover, the thermochemical treatment clearly highlighted the vegetal and fibrous structure of the materials, revealing the cellular skeleton of the biomass. This finding seems more evident for the sample after extraction, due to the removal of soluble components operated by the solvent leaving the structure more accessible. So far, the ESEM analyses did not exhibit marked differences between polar (acetone) and nonpolar (hexane) solvents, both being capable to well flush the internal microstructure from soluble components at micrometer scale.
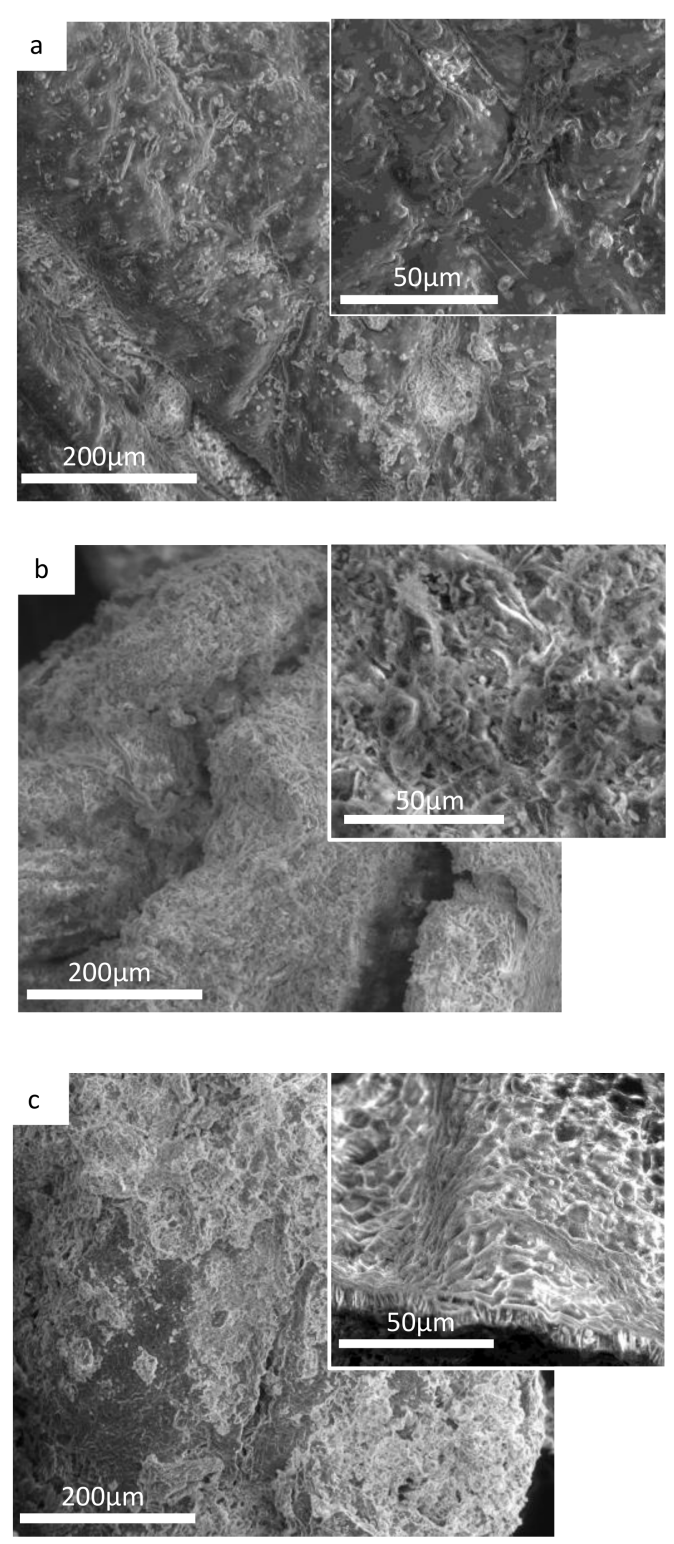

Figure 7. ESEM images of selected solid samples: (a) as-given biomass; (b) converted biomass after extraction with hexane; (c) converted biomass after extraction with acetone.

Figure 8 shows a qualitative comparison between spectra obtained from ATR-FTIR analysis of the extracted species from marc and converted marc. The spectrum of acetone, the solvent used for the extraction, is also reported for comparison. The typical peaks of acetone are well visible in all the spectra: as at $1710 \mathrm{~cm}^{-1}$ the $\mathrm{C}=\mathrm{O}$ stretch band is evident and at $\sim 1220 \mathrm{~cm}^{-1}$ the C-C stretch band. In spectra 2 and 3, new marked peaks appear in the region between $2800-3100 \mathrm{~cm}^{-1}$. Those are well comparable to literature data for vegetable oils [27] and can be due to the presence of aliphatic carboxylic acids deriving 
from the extraction in acetone, and can be attributed to a mixture of oils (e.g., linoleic, oleic, palmitic, etc.) typically present in grape seeds [24]. Indeed, carboxylic acids show a strong, wide broad band for the $\mathrm{O}-\mathrm{H}$ stretch in the region $2500-3300 \mathrm{~cm}^{-1}$. That is in the same region as the $\mathrm{C}-\mathrm{H}$ stretching bands of both alkyl and aromatic groups. Therefore, carboxylic acids show an articulated absorption pattern in the region $2500-3300 \mathrm{~cm}^{-1}$, with the broad $\mathrm{O}-\mathrm{H}$ band superimposed on the sharp $\mathrm{C}-\mathrm{H}$ stretching bands. The carbonyl $\mathrm{C}=\mathrm{O}$ stretch of the carboxylic acid appears as an intense band from $1760-1690 \mathrm{~cm}^{-1}$, evident for sample (2), marc in acetone, and attenuated and covered for the sample (3), marc after PSC. Other typical absorptions are associated to the C-O stretching in the region $1320-1210 \mathrm{~cm}^{-1}$, and the $\mathrm{O}-\mathrm{H}$ bend at $1395-1440 \mathrm{~cm}^{-1}$ and $910-950 \mathrm{~cm}^{-1}$, although the latter region may can be hardly distinguished from $\mathrm{C}-\mathrm{H}$ bending bands in the same region.

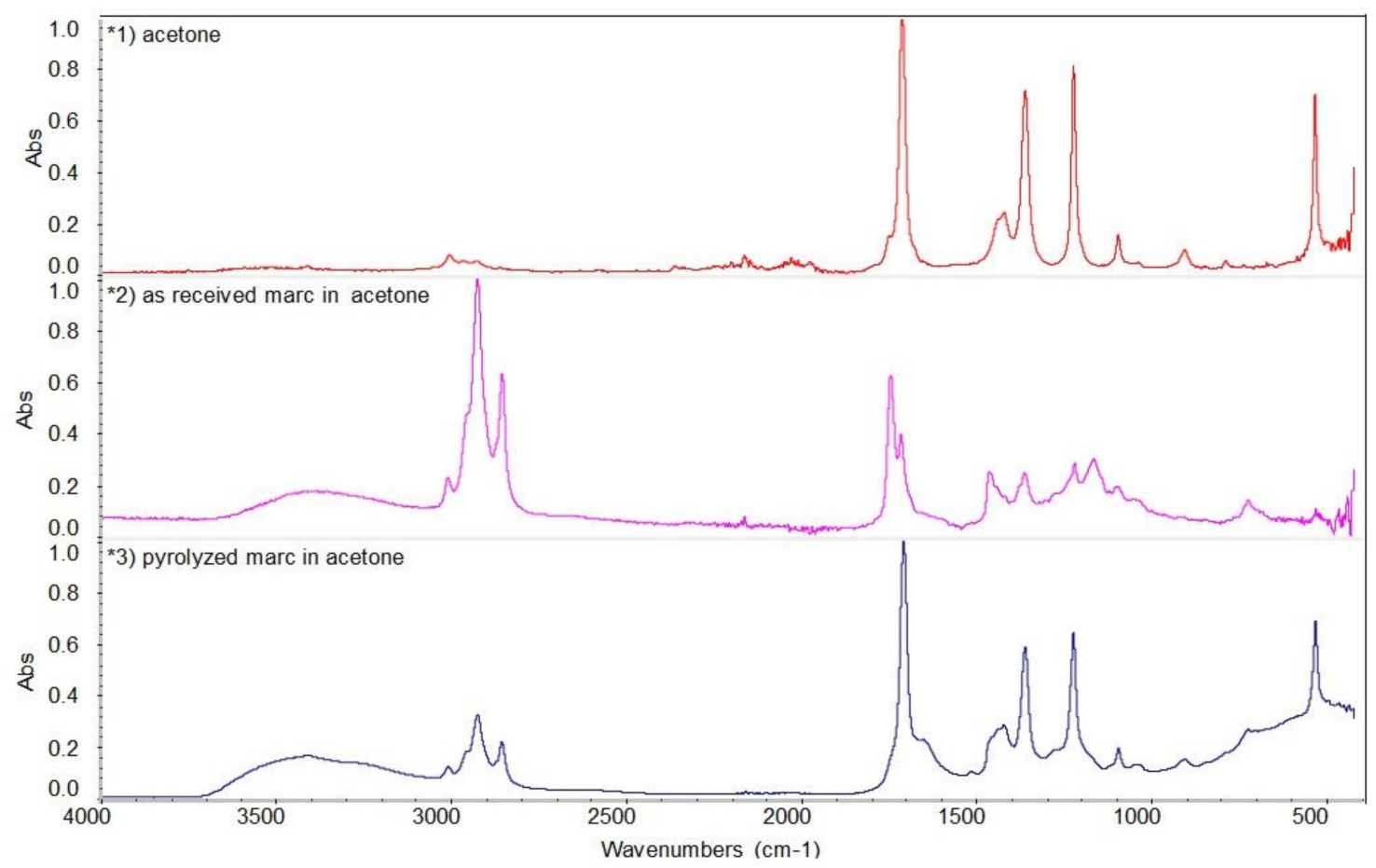

Figure 8. Comparison among FTIR spectra of: (1) pure acetone; (2) liquid phase from extraction of as received biomass in acetone; (3) liquid phase from extraction of converted biomass in acetone.

\section{Discussion}

The use of marc in PSC process under similar conditions as other residues (olive and tomato) reported in literature [19] led to slightly higher solid fraction and lower liquid fraction, as reported in Table 2. Such different behavior may be attributed to the difference in chemical composition among the residues, in particular the higher lignin content of marc, being lignin less reactive than cellulose in hydrothermal treatment [28].

The pressurized steam conversion had a prominent role in degradation of the organic constituents of the biomass, whose products remained locked in large extent inside the porosity of the biochar. The process evolution was monitored by the pressure increase in the reactor due to water evaporation, volatiles release and hydrolysis of biomass constituents. For instance, the cellulose hydrolysis, i.e., sugars formation and their decomposition, likely occurs in the temperature range $150-250{ }^{\circ} \mathrm{C}$, with generation of lighter condensable and gas/vapor species [29]. However, the overall kinetics were slow because of the limited operating temperature [30], as revealed by the long time, in excess of $30 \mathrm{~min}$, required to achieve a stable pressure value. The difference in the dynamic behavior of temperature and pressure data (Figure 4) can be ascribed to different mechanisms: (i) physical heat transfer limited only by the convection/conduction mechanisms [31]; (ii) slow degradation 
reactions of the solid biomass into gas and vapors [32], leading to pressure increase. From a kinetic perspective, the biomass pyrolysis exhibits different activation energies in different ranges of temperature [32]; the very low temperature range (i.e., $<800 \mathrm{~K}$ ), as the case of this study, has the highest activation energy. Consequently, the release of liquid and gas products during devolatilization and associated pressure increase is much slower than temperature rise.

Table 2. Comparison of yield in solid and liquid among different biomass residues. Data of olive husks and tomato peels are reproduced with permission from authors [19].

\begin{tabular}{ccc}
\hline & $\mathbf{X}_{\mathbf{s}}$ & $\mathbf{X}_{\mathbf{1}}$ \\
\hline Marc (this work) & $0.60-0.80$ & $0.20-0.38$ \\
Olive husks [19] & $0.38-0.70$ & $0.45-0.50$ \\
Tomato peels [19] & $0.30-070$ & $0.13-0.58$ \\
\hline
\end{tabular}

The subsequent extraction with solvent, either polar or nonpolar, allowed the release of the organic liquid fraction, leading to a solid residue with internal microstructure more accessible, as evidenced by ESEM analysis. The extraction time in solvent largely affected the extent of liquid fraction that was higher for prolonged extraction. This effect can be attributed to the loss in permeability of soluble species in the biochar internal porosity, in particular submicronic pores due to the lenght of some diffusing species (e.g., C-18 linoleic acid). Nonpolar solvent seems to be more effective in the extraction step, preventing large wetting of the particles, due to the hygroscopic character of biochar produced at moderate temperature [26]. The alternative method of quick evacuation and condensation of all vapors contained in the reactor after PSC yielded high liquid fraction, although leading to a large water content, being water vapor removed from the reactor and condensed. However, this method deserves further investigation, being basically simpler and solvent free.

FTIR analyses showed that typical carboxylic acids of marc residues [24] are detectable in both extracted liquid fractions from as-received and converted biomass, although in the former the characteristic peaks appear attenuated as consequence of the chemical degradation into lighter hydrocarbons during the thermochemical treatment.

Ultimately, the investigated protocol of pressurized steam conversion of biomass in presence of water provided useful insights for a possible implementation at larger scale and steady operation mode: role of residence time, extraction time, type of solvent to be used. It is worth noting that the proposed method is much simpler, if compared to biomass liquefaction in hydrothermal conditions that hardly can be carried out under steady operation.

\section{Conclusions}

Marc from winemaking was converted via PSC and solvent extraction under process conditions already investigated as other biomass residues (olive husks and tomato peels). The comparison of quantitative yields in solid and liquid fraction reveals that marc is less reactive because of the higher lignin content. However, liquid yield up to $30 \mathrm{wt}$ \% of the initial samples was achieved.

The investigation of the process operating conditions demonstrated the large effect of the residence time in the pressurized reactor and extraction time in solvent, both improving the obtained liquid fraction. The use of a nonpolar solvent was favorable due to the hygroscopic character of the biochar produced by PSC.

The proposed method can be considered effective for conversion and stabilization of biomass residues that can undergo biological degradation if stocked, owing to the relative easiness of its implementation with respect to more complex processes, as hydrothermal liquefaction.

Further developments of the research will be oriented at enhancing the formation of the liquid fraction, deeply characterize its chemical composition, determining the conver- 
sion by PSC of biomass constituents and at providing insights for designing a continuous PSC process.

Author Contributions: Conceptualization, F.M., E.L. and M.M.; methodology, F.M., E.P. and A.N.M.; investigation, F.M. and E.L.; writing, F.M. and M.M. All authors have read and agreed to the published version of the manuscript.

Funding: The research was carried without external resources as a curiosity driven activity.

Institutional Review Board Statement: Not applicable.

Informed Consent Statement: Not applicable.

Data Availability Statement: Not applicable.

Acknowledgments: N. Randi is gratefully acknowledged for the conduction of the experimental tests in the frame of a degree work.

Conflicts of Interest: The authors declare no conflict of interest.

\section{References}

1. Bridgwater, A.V. Renewable fuels and chemicals by thermal processing of biomass. Chem. Eng. J. 2003, 91, 87-102. [CrossRef]

2. Näyhä, A. Transition in the Finnish forest-based sector: Company perspectives on the bioeconomy, circular economy and sustainability. J. Clean. Prod. 2019, 209, 1294-1306. [CrossRef]

3. Nanda, S.; Mohammad, J.; Reddy, S.N.; Kozinski, J.A.; Dalai, A.K. Pathways of lignocellulosic biomass conversion to renewable fuels. Biomass Conv. Bioref. 2014, 4, 157-191. [CrossRef]

4. Chandolias, K.; Richards, T.; Taherzadeh, M.J. 5-Combined Gasification-Fermentation Process in Waste Biorefinery. In Waste Biorefinery; Bhaskar, T., Pandey, A., Mohan, S.M., Lee, D.J., Khanal, S.K., Eds.; Elsevier: Amsterdam, The Netherlands, 2018; pp. 157-200.

5. Bridgwater, A.V.; Bridge, S.A. A Review of Biomass Pyrolysis and Pyrolysis Technologies. In Biomass Pyrolysis Liquids Upgrading and Utilization; Bridgwater, A.V., Grassi, G., Eds.; Springer: Dordrecht, The Netherlands, 1991.

6. Babler, M.U.; Phounglamcheik, A.; Amovic, M.; Ljunggren, R.; Engvall, K. Modeling and pilot plant runs of slow biomass pyrolysis in a rotary kiln. Appl. Energy 2017, 207, 123-133. [CrossRef]

7. Li, Y.; Xing, B.; Ding, Y.; Han, X.; Wang, S. A critical review of the production and advanced utilization of biochar via selective pyrolysis of lignocellulosic biomass. Bioresour. Technol. 2020, 312, 123614. [CrossRef]

8. Collard, F.X.; Blin, J. A review on pyrolysis of biomass constituents: Mechanisms and composition of the products obtained from the conversion of cellulose, hemicelluloses and lignin. Renew. Sustain. Energy Rev. 2014, 38, 594-608. [CrossRef]

9. León, M.; Silva, J.; Carrasco, S.; Barrientos, N. Design, Cost Estimation and Sensitivity Analysis for a Production Process of Activated Carbon from Waste Nutshells by Physical Activation. Processes 2020, 8, 945. [CrossRef]

10. Zhang, Q.; Chang, J.; Wang, T.; Xu, Y. Review of biomass pyrolysis oil properties and upgrading research. Energy Convers. Manag. 2007, 48, 87-92. [CrossRef]

11. Alakoski, E.; Jämsén, M.; Agar, D.; Tampio, E.; Wihersaari, M. From wood pellets to wood chips, risks of degradation and emissions from the storage of woody biomass-A short review. Renew. Sustain. Energy Rev. 2016, 54, 376-383. [CrossRef]

12. Nordin, A.; Pommer, L.; Nordwaeger, M.; Olofsson, I. Biomass conversion through torrefaction. In Technologies for Converting Biomass to Useful Energy: Combustion, Gasification, Pyrolysis, Torrefaction and Fermentation; Dahlquist, E., Ed.; CRC Press: Boca Raton, FL, USA, 2013; pp. 217-240.

13. Barskov, S.; Zappi, M.; Buchireddy, P.; Dufreche, S.; Guillory, J.; Gang, D.; Hernandez, R.; Bajpai, R.; Baudier, J.; Cooper, R.; et al. Torrefaction of biomass: A review of production methods for biocoal from cultured and waste lignocellulosic feedstocks. Renew. Energy 2019, 142, 624-642. [CrossRef]

14. Arias, B.; Pevida, C.; Fermoso, J.; Plaza, M.G.; Rubiera, F.; Pis, J.J. Influence of torrefaction on the grindability and reactivity of woody biomass. Fuel Proc. Technol. 2008, 89, 169-175. [CrossRef]

15. Libra, J.A.; Ro, K.S.; Kammann, C.; Funke, A.; Berge, N.D.; Neubauer, Y.; Titirici, M.M.; Fühner, C.; Bens, O.; Kern, J.; et al. Hydrothermal carbonization of biomass residuals: A comparative review of the chemistry, processes and applications of wet and dry pyrolysis. Biofuels 2011, 2, 71-106. [CrossRef]

16. Gollakota, A.R.K.; Kishore, N.; Gu, S. A review on hydrothermal liquefaction of biomass. Renew. Sustain. Energy Rev. 2018, 81, 1378-1392. [CrossRef]

17. Fiori, L.; Basso, D.; Castello, D.; Baratier, M. Hydrothermal Carbonization of Biomass: Design of a Batch Reactor and Preliminary Experimental Results. Chem. Eng. Trans. 2014, 37, 55-60.

18. Elliott, D.C.; Biller, P.; Ross, A.B.; Schmidt, A.J.; Jones, S.B. Hydrothermal liquefaction of biomass: Developments from batch to continuous process. Bioresour. Technol. 2015, 178, 147-156. [CrossRef] [PubMed]

19. Brachi, P.; Miccio, F.; Ruoppolo, G.; Miccio, M. Pressurized Steam Torrefaction of Biomass: Focus on Solid, Liquid, and Gas Phase Distributions. Ind. Eng. Chem. Res. 2017, 56, 12163-12173. [CrossRef] 
20. Brachi, P.; Miccio, F.; Miccio, M.; Ruoppolo, G. Torrefaction of tomato peel residues in a fluidized bed of inert particles and a fixed-bed reactor. Energy Fuels 2016, 30, 4858-4868. [CrossRef]

21. Scoma, A.; Rebecchi, S.; Bertin, L.; Fava, F. High impact biowastes from South European agroindustries as feedstock for second-generation biorefineries. Crit. Rev. Biotechnol. 2016, 36, 175-189. [CrossRef]

22. Channiwala, S.A.; Parikh, P.P. A unified correlation for estimating HHV of solid, liquid and gaseous fuels. Fuel 2002, 81, 1051-1063. [CrossRef]

23. Krajnc, N. Wood Fuels Handbook; Food and Agriculture Organization of the United Nations: Pristina, Kosovo, 2015.

24. Rombaut, N.; Savoire, R.; Thomasset, B.; Bélliard, T.; Castello, J.; Van Hecke, E.; Lanoisellé, J.L. Grape seed oil extraction: Interest of supercritical fluid extraction and gas-assisted mechanical extraction for enhancing polyphenol co-extraction in oil. Comptes Rendus Chim. 2014, 17, 284-292. [CrossRef]

25. Stelte, W. Torrefaction of Unutilized Biomass Resources and Characterization of Torrefaction Gasses; Resultat Kontrakt (RK) Report Danish Technological Institut: Taatstrut, Denmark, 2012.

26. Chen, W.H.; Lin, B.J.; Colin, B.; Pétrissans, A.; Pétrissans, M. A study of hygroscopic property of biomass pretreated by torrefaction. Energy Procedia 2019, 158, 32-36. [CrossRef]

27. Yang, H.; Irudayaraj, J.; Paradkar, M.M. Discriminant analysis of edible oils and fats by FTIR, FT-NIR and FT-Raman spectroscopy. Food Chem. 2005, 93, 25-32. [CrossRef]

28. Borrero-López, A.M.; Masson, E.; Celzard, A.; Fierro, V. Modelling the reactions of cellulose, hemicellulose and lignin submitted to hydrothermal treatment. Ind. Crop. Prod. 2018, 124, 919-930. [CrossRef]

29. Mohan, M.; Timung, R.; Deshavath, N.N.; Banerjee, T.; Goud, V.V.; Dasu, V.V. Optimization and hydrolysis of cellulose under subcritical water treatment for the production of total reducing sugars. RSC Adv. 2015, 5, 103265. [CrossRef]

30. Ranzi, E.; Cuoci, A.; Faravelli, T.; Frassoldati, A.; Migliavacca, G.; Pierucci, S.; Sommariva, S. Chemical Kinetics of Biomass Pyrolysis. Energy Fuels 2008, 22, 4292-4300. [CrossRef]

31. Bird, R.B.; Stewart, W.E.; Lightfoot, E.N. Transport Phenomena, 2nd ed.; Wiley: Hoboken, NJ, USA, 2007.

32. Di Blasi, C. Modeling chemical and physical processes of wood and biomass pyrolysis. Prog. Energy Combust. Sci. 2008, 34, 47-90. [CrossRef] 